\title{
STUDI KORELASI WPT ( WONDERLIC PERSONNEL TEST ) DAN IST ( INTELLIGENZ STRUCTUR TEST )
}

\author{
Sulisworo Kusdiyati \\ Fakultas Psikologi Universitas Islam Bandung \\ Jl. Tamansari No.1 Bandung 40116 Telp (022) 4205546 email: sulisworokusdiyati@ gmail.com
}

\begin{abstract}
Psychological testing in high school, university and assessment of new employee were used in order to ease stakeholder for sorting and placement purpose. These tests generally include intellectual capability, personality test and performance test. There are numerous tests that can be used for this purpose and some of them quite popular among many assessor such as IST-70 and WPT. However it is known that the intelligence score as result from IST-70 and WPT were quite different. IQ score from WPT generally resulted 1-5 point lower from IST. The question now is which is from both test that considered as a valid result? This research was conducted in purpose of gathering empirical data regarding s-factor and g-factor in IST, correlation element between WPT and IST, and last differences between both tests. Thus, this research can be considered as correlation research. The assumption used in this research are (1) correlation between subtest in IST, (2) subtest in IST with WPT;(3) IQ score result with WPT and IST; and (4) differences between of IQ score resulted by WPT and IST. It was then concluded that IST measure s-factor and g-factor while WPT only measure g-factor.
\end{abstract}

Keywords: test of Intelligence, $g$ - factor, s- factor

\section{Pendahuluan}

Penggunaan tes kecerdasan di Indonesia baru dimulai pada awal tahun 1950-an. Sejak saat itu penggunaan tes kecerdasan berkembang luas. Tes kecerdasan merupakan bagian dari tes kemampuan (ability test) dan biasanya digunakan untuk keperluan seleksi dan penempatan pemekerjaan di perusahaan, keperluan penjurusan di SLTA dan perguruan tinggi, keperluan seleksi calon siswa SLTP/SLTA atau seleksi calon mahasiswa. Tes kecerdasan dipakai untuk mengukur atau menilai kemampuan dasar atau kecerdasan yang dimiliki oleh seorang individu secara obyektif. Ada beberapa tes kecerdasan yang dalam prakteknya sering dipakai sebagai salah satu baterai tes untuk keperluan seleksi di perusahaan atau untuk penjurusan pendidikan. Tes yang dimaksud adalah IST-70. IST-70 adalah tes kecerdasan yang diciptakan oleh Rudolf Amthauer. Tes ini terdiri dari 9 subtes. Dalam sudut pandang Amthauer Intelegensi adalah suatu struktur tersendiri didalam keseluruhan struktur kepribadian seorang manusia. Inteligensi merupakan suatu keseluruhan struktur kemampuan-kemampuan jiwa dan rohani yang berfungsi sedemikian rupa sehingga memberikan kemampuan bagi manusia untuk bertindak sebagai pelaksana dalam dunianya. IST dimaksudkan untuk mengukur ' $g$ '- factor dan 's'-factor. Sedangkan tes inteligensi lainnya yang juga memiliki popularitas yang tinggi adalah WPT (Wonderlic Personnel Test). Tes ini dirancang pertama kali oleh E.F Wonderlic pada tahun 1936. Sampai saat artikel ini ditulis, WPT telah direvisi beberapa kali. Revisi terakhir dilakukan pada tahun 2006 (WPT-R). Pada prinsipnya tes WPT ini dimaksudkan 
untuk mengukur kemampuan inteligensi umum atau ' $g$ '-factor.

Dalam prakteknya apabila kedua tes tersebut digunakan secara bersama-sama untuk mengetahui gambaran kecerdasan dari calon pegawai, atau calon mahasiswa baru, maka terdapat perbedaan skor IQ dari keduanya dalam kisaran 5-15 poin, dimana pada umumnya skor WPT lebih rendah daripada skor IST. Dengan kata lain nilai IQ yang diperoleh dengan menggunakan IST pada umumnya lebih tinggi sekitar 15 poin dari nilai IQ yang diperoleh dengan WPT. Pertanyaan yang kemudian muncul adalah : apakah hasil kedua tes tersebut valid? Apakah hasil dari keduanya dapat dikatakan setara?. Hal inilah yang menarik perhatian peneliti untuk melakukan penelitian lebih lanjut.

Merujuk kepada hal di atas maka perumusan masalah dalam penelitian ini adalah :

1. Apakah IST mengukur s-factor dan $g$ factor?

2. Sejauhmana hasil tes WPT dan IST berhubungan (correlated)?

3. Apakah hasil tes WPT dan IST dapat dikatakan berbeda?

Penelitian ini dilakukan dengan tujuan untuk :

1. Mendapatkan data empiris apakah IST mengukur s-factor dan $g$-factor.

2. Mendapatkan data empiris tentang korelasi WPT dan IST

3. Mendapatkan data empiris tentang perbandingan hasil tes WPT dan IST.
Pada mulanya adalah sulit untuk mendefinisikan kecerdasan. Para pakar mencoba untuk memahami inteligensi dengan beragam pendekatan. Ada dua pendekatan besar yang sering digunakan untuk memahami kecerdasan. Yang pertama adalah pendekatan kognitif (cognitive approach). Sedangkan yang kedua adalah pendekatan pengukuran psikometri (psychometric approach). Pendekatan kognitif atau disebut juga dengan pendekatan konsep, berpandangan bahwa kecerdasan dapat didefinisikan dengan berbagai cara. Artinya kecerdasan dapat mewujud dalam berbagai macam cara atau bentuk sehingga tidak ada satu alat tes pun yang dapat mengukurnya.

Diantara teori yang termasuk pendekatan kognitif adalah teori kecerdasan yang dikemukakan Howard Gardner yang mengusulkan bahwa kecerdasan sebagai sesuatu yang jamak (multiple independent intelligences). Menurut Gardner kecerdasan-kecerdasan tersebut adalah : musical Intelligence, bodily-kinesthetic intelli-gence, logical mathematical intelli-gence, linguistic intelligence, spatial intelligence, inter-personal intelligence, intrapersonal intelligence, naturalist intelligence and spiritual intelligence. Teori lain tentang kecerdasan juga diajukan oleh seorang psikolog dan peneliti dari Yale University, Robert Sternberg yang popular dengan konsepsinya tentang triarchic theory and successful intelligence. Sedangkan psikolog lainnya, Daniel Goleman telah lebih dulu popular dengan teorinya tentang emotional intelligence. Jika ditelaah lebih jauh teori-teori ini memiliki konsepsi teoritis yang 
cukup baik, namun secara umum masih belum dapat dioperasionalkan ke dalam suatu metodologi pengukuran yang valid dan reliabel.

Di sisi lain pendekatan psikometri berpandangan bahwa kecerdasan haruslah dapat diukur. Pemikiran dasarnya adalah bahwa kecerdasan itu harus proven (dapat dibuktikan) dan harus basic evidence (berdasarkan bukti empiris). Menurut pendekatan psikometri, Tes IQ berfokus pada kinerja individu saat mengerjakan tes-tes terstandar yang dirancang untuk mengukur kecakapan dan pengetahuan yang sudah dipelajari. Diantara para ahli yang menganut pendekatan psikometri ini, diantaranya adalah Alfred Binet, Lewis Terman, William Stern, Charles Spearman, David Wechsler, E.F Won-derlic, dan Linda. S Gottfredson.

Pada tahun 1994, pasca kontroversi atas terbitnya buku "The Bell Curve" karya Richard J. Herrnstein dan Charles Murray yang kemudian memicu perdebatan sengit di kalangan ilmuwan tentang apakah kecerdasan sebagai sesuatu yang lebih merupakan pengaruh faktor keturunan (genetic) ataukah lebih karena pengaruh faktor lingkungan (environment), para pakar dan peneliti intelegensi telah membuat suatu konsensus bersama yang dinyatakan dalam "Mainstream Science on Intelligence" yang terbit pada tanggal 13 Desember 1994 (lihat : Mainstream Science on Intelligence, An Editorial With 52 Signatories, His-tory, and Bibliograph, yang dikoordinasikan penulisannya oleh Prof. Linda S. Gottfredson, Ph.D dari University of Dela- ware). Dalam editorial tersebut kecerdasan dinyatakan sebagai berikut :

"Intelligence is a very general mental capability that, among other things, involves the ability to reason, plan, solve problems, think abstractly, comprehend complex ideas, learn quickly and learn from experience."

Beberapa konsensus yang disepakati oleh para pakar intelegensi dalam editorial tersebut diatas antara lain adalah sebagai berikut :

1. Kecerdasan adalah kapasitas mental yang sangat umum, yang meliputi kemampuan bernalar, merencanakan, memecahkan masalah, berpikir abstrak, memahami gagasan kompleks, belajar dengan cepat dan belajar dari pengalaman. Lebih lanjut Gottfredson menyatakan bahwa kecerdasan bukanlah sekedar kemampuan belajar dari buku, suatu kecakapan akademik tertentu, atau semata kemampuan menyelesaikan tes dengan baik (test taking) namun lebih luas dari itu. Kecerdasan mencerminkan kemampuan yang lebih luas dan mendalam untuk memahami lingkungan sekitar - "catching on " / menangkap suatu gejala di lingkungan, "making sense of things

"/ membuat sesuatu tampak masuk akal, atau " figuring out" what to do "/ membuat gambaran menyeluruh tentang apa harus dilakukan.

2. Kecerdasan, oleh karena itu dapat diukur, dan tes kecerdasan dapat mengukur kecerdasan dengan baik. Tes kecerdasan adalah tes yang paling akurat ( valid and reliable) dari keseluruhan tes-tes psikologi. Tes kecerdasan tidak mengukur kreativitas, karakter, kepribadian 
atau faktor lain yang dapat membedakan individu.

3. Meski terdapat beragam tipe tes kecerdasan, tes-tes tersebut sesung-guhnya mengukur substansi yang sama. Diantara tes-tes tersebut ada yang menggunakan kata-kata atau angkaangka dan mempersyaratkan pengetahuan spesifik untuk budaya tertentu (misal: vocabulary). Adapun tes yang lain menggunakan bentukbentuk atau desain-desain dan mempersyaratkan pengetahuan tentang konsep-konsep yang umum ( banyak/sedikit, terbuka/ tertutup, di atas/ dibawah)

4. Individu yang dites nantinya dapat diketahui posisinya dalam skala IQ yang bersifat kontinum dari IQ rendah hingga IQ tinggi yang digambarkan dalam kurva normal. Kebanyakan orang mengelompok di sekitar rata-rata $(\mathrm{IQ}=100)$, sedikit yang berada di kelompok sangat cemerlang (very bright) atau sangat bodoh (very dull). Sekitar $3 \%$ memiliki skor di atas IQ 130 (giftedness), dan $3 \%$ juga yang memiliki skor di bawah IQ $=70$ (mental retardation).

Seorang pakar kecerdasan dengan pendekatan psikometri adalah Charles Spearman (1863-1945). Beliau mencoba memahami kecerdasan dengan pendekatan analisis faktor. Beliau mengemukakan bahwa kecerdasan terdiri dari g-factor dan s-factor. Menurut Spearman, $g$ factor adalah indeks kemampuan mental umum atau indeks inteligensi, dan indeks ini menggambarkan kemampuan mental yang bersifat "inventive" (untuk menemukan hal-hal baru, pemecahan-pemecahan masalah baru) daripada kemampuan mental yang ber- sifat "reproduktif' (mereproduksi hal-hal yang sudah ada sebelumnya ) (Arthur Jensen, 1979 dalam Sattler, 2001).

Adapun s-factor adalah kemampuankemampuan spesifik yang tidak berhubungan. Suatu tes kecerdasan pada umumnya berisi beragam tipe pertanyaan. Pertanyaan yang muncul adalah apakah ini berarti tes kecerdasan mengukur kemampuan-kemampuan kolektif yang saling berhubungan atau kemampuan tunggal ataukah tes kecerdasan ini mengukur kemampuan-kemampuan yang spesifik / khusus yang tidak saling berhu-bungan?.

Untuk menguji hal ini, Spearman kemudian mengkorelasikan kemampuan-kemampuan (misal numerik, verbal, penalaran spasial) yang diukur oleh tes kecerdasan. Apabila ditemukan korelasi yang tinggi diantara bagian yang berbeda dari tes kecerdasan, maka dikatakan bahwa performance test-test tersebut sebagian besar bersumber dari suatu single factor. Single factor inilah yang kemudian oleh Spearman disebut sebagai ' $g$ ' (general intelligence). Apabila ditemukan korelasi yang rendah atau tidak ada korelasi diantara bagian yang berbeda dari tes kecerdasan, maka dikatakan bahwa performance test-test tersebut bersumber dari faktor - faktor yang berbeda (s-factor).

Apakah g-factor atau general intelligence tersebut sebenarnya?. Gottfredson (1998) menyatakan di awal abad 20 penelitipeneliti kecerdasan menemukan bahwa seluruh tes kemampuan mental yang ada me-rangking individu dalam cara yang sama. Meskipun testes mental tersebut sering didesain untuk 
mengukur domain kognitif yang spesifik verbal fluency, mathematical skill, spatial visualization atau memory - orang-orang yang mampu mengerjakan dengan baik di suatu tes mental cenderung berhasil baik juga dalam menger-jakan tes mental yang lain, dan orangorang yang tidak mampu mengerjakan dengan baik di suatu tes mental biasanya akan buruk juga hasilnya di tes mental yang lain. Interkorelasi ini menyatakan bahwa tes-tes mental tersebut mengukur elemen global kemampuan intelektual, disamping mengukur kecakapan kognitif yang spesifik. Dalam 20 tahun terakhir pakar-pakar kecerdasan telah berusaha untuk mengisolasi (mengekstrak) faktor umum ini dari aspek-aspek kemampuan kognitif lain dalam tes-tes kemampuan mental tersebut. Kemampuan umum ini secara statistik dapat diekstrak dengan apa yang disebut sebagai teknik analisis faktor yang diperkenalkan oleh Charles Spearman. Spearman mengamati bahwa faktor umum muncul dari analisisnya terhadap tes-tes yang mengukur kemampuan mental. Hal inilah yang kemudian mengarahkan Arthur R. Jensen dan John B. Carroll untuk mengkonfirmasikan penemuan ini, sehingga pakar kecerdasan sekarang menggunakan faktor umum sebagai definisi kerja kecerdasan. Faktor kemampuan umum ini yang selanjutnya popular disebut sebagai $g$-factor merupakan unsur aktif ( active ingredient) dari semua tes yang menguji kemampuan mental manusia.

Untuk mendapatkan kejelasan tentang faktor umum atau g-factor, berikut akan dipaparkan The Three Stratum Hierarchical
Structur of Mental Abilities - atau dikenal juga sebagai CHC (Cattel-Horn-Carroll) Theory of Cognitive Abilities atau Carroll's ThreeStratum Factor Analytic Theory of Cognitive Abilities (dalam Sattler, 2008). Teori ini diperkenalkan pada tahun 1993. Dalam hierarki ini terdapat 3 strata atau level kemampuan mental manusia. Pada strata 3 (level paling atas atau disebut level umum/general) terdapat hanya satu kemampuan mental yang disebut kecerdasan umum (g-factor). Disebut demikian karena kemampuan kognitif yang ada pada level ini merupakan essence atau tulang punggung bagi setiap proses mental kemampuankemampuan yang ada dibawahnya. Kemudian pada strata atau level 2 ( di bawah strata 3) terdapat antara 8 kemampuan mental yang lebih spesifik yang disebut sebagai faktor luas (broad factor). Termasuk ke dalam strata ini adalah fluid intelligence/reasoning (Gf), crystallized intelligence $(G c)$, general memory and learning (Gy), broad visual perception $(G v)$, broad auditory perception $(G u)$, broad retrieval ability $(\mathrm{Gr})$, broad cognitive speediness (Gs) dan processing speed /decision speed $(G t)$. Selanjutnya pada strata 1 atau level paling bawah terdapat 65 kemampuan-kemampuan mental yang sangat spesifik atau dikenal sebagai faktor spesifik (narrow factor). Misalnya fluid intelligence / reasoning (broad factor) mencakup general sequential reasoning, induction, quantitative reasoning, dan speed of reasoning (narrow factor / s-factor) (Sattler, 2008). 


\section{Carroll's (1993) Three-Stratum Theory of Cognitive Abilities}

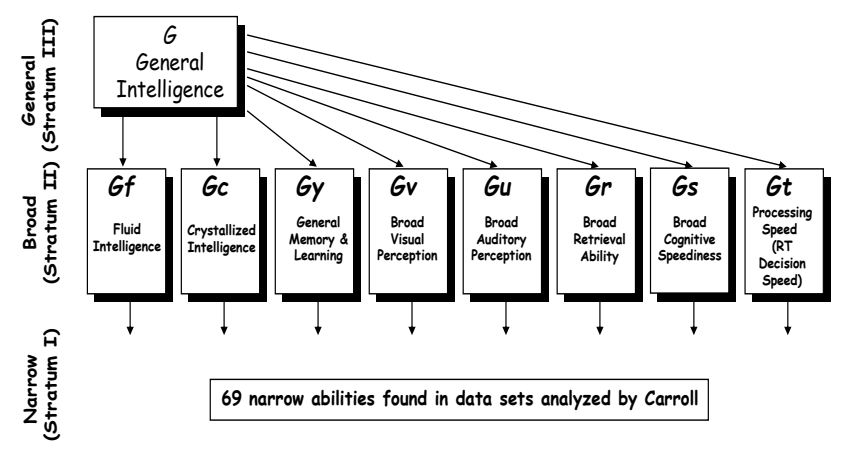

Gambar 1. Tiga tingkatan dalam kemampuan berpikir

Berdasarkan penjelasan di atas yang menerangkan mengenai tingkat generalitas faktor kecerdasan umum, maka tidaklah mengejutkan jika g-factor disebut sebagai manifestasi dari kecakapan berpikir yang bersifat generik (mendasar). Manifestasi kecakapan atau kemampuan berpikir generik ini biasanya diasosiasikan dengan kemampuan belajar yang cepat dan efisien, kemampuan bernalar yang tinggi, kemampuan berpikir secara abstrak, dan kemampuan memecahkan masalah.

Selanjutnya Gottfredson (2002) menjelaskan $g$ sebagai suatu konstruk. Menurut beliau memahami $g$ sebagai suatu konstruk adalah seperti kita memahami arti mendasar dari suatu kemampuan / ability - adalah suatu yang sangat penting untuk memahami mengapa dan dimana $g$ dapat memperkaya kinerja individu dalam melakukan tugas sehari-hari. Makna praktis $g$ dapat dilihat dari perilaku overt dan keterampilan mental yang merupakan prototip $g$ - yaitu yang dapat dengan sangat baik membedakan orang-orang dengan level $g$ tinggi dari orang-orang dengan level $g$ rendah. Tes kecerdasan dibuat dengan maksud untuk mengukur variasi keterampilan berpikir tingkat tinggi (higher order thinking skill), seperti menalar (reasoning), berpikir secara abstrak (abstract thunking) dan memecahkan masalah (problem solving), dimana orang yang pandai dan bodoh dinilai berdasarkan aspek krusial inteligensi. $g$ ternyata juga berkorelasi tinggi dengan tes kemampuan mental spesifik dari suatu tes bakat tertentu. Keterampilanketerampilan tingkat tinggi (higher order skills) ini adalah konteks dan konten dari keterampilan mental independen yang dapat diterapkan secara umum. Kebutuhan untuk bernalar, belajar dan memecahkan masalah ada dimanamana dan terjadi sepanjang hayat, sehingga secara intuitif $g$ memiliki nilai yang tinggi dan lebih dari hanya sekedar "kepandaian yang diperoleh dari membaca buku".

Kita juga dapat memaknai $g$ dengan melihat apa yang ada dibalik korelasi berbagai domain kemampuan manusia. Menurut Carroll (1993), suatu kemampuan / ability adalah suatu atribut individual yang dinyatakan/ muncul karena adanya perbedaan tingkat kesulitan tugas pada/dari sekelompok tugas-tugas tertentu dimana individu dapat menunjukkan keberhasilan ketika kondisi bagi performance yang maksimal dimungkinkan. Apabila kita membandingkan tes-tes atau item-item kemampuan mental, maka kita dapat melihat bahwa item-item yang lebih bermuatan $g$ adalah item-item yang lebih kompleks, apapun kontennya. Item-item tersebut umumnya mempersyaratkan kemampuan memproses infor- 
masi yang lebih kompleks. Tabel berikut ini mengilustrasikan hal tersebut.

Tabel 1. Kemampuan memproses informasi

\begin{tabular}{|l|l|l|}
\hline Perintah & Item sederhana & Item kompleks \\
\hline menghitung & $0,5 \times 6=3,00$ & $\begin{array}{l}\text { Harga sebuah apel 0,5 } \\
\text { rupiah. Susan membeli 6 } \\
\text { buah apel. Berapa uang } \\
\text { yang harus dibayarkan } \\
\text { susan ? }\end{array}$ \\
\hline mendefinisikan & Meja & merenungkan \\
\hline $\begin{array}{l}\text { Sebutkan } \\
\text { persamaannya }\end{array}$ & Pir - apel & Benih - telur \\
\hline $\begin{array}{l}\text { Berikan dua } \\
\text { angka } \\
\text { berikutnya }\end{array}$ & $2,4,6,8,--,--$ & $11,10,9,10,9,8,--,--$, \\
\hline
\end{tabular}

Item di kolom 3 lebih kompleks daripada item yang terdapat di kolom 2, tanpa mempertimbangkan tipe item dan tanpa mempertimbangkan apakah item-item tersebut tampak lebih 'akademik'. Item pertama baris pertama pada kolom 2 mempersyaratkan hanya hitungan sederhana. Berlawanan dengan item di kolom 3, dimana item pada kolom tersebut memang mempersyaratkan hitungan, namun sebelumnya orang harus memastikan perhitungan yang bagaimana yang harus dibuatnya. Item-item persamaan pada baris ke 3, berbeda dalam hal keabstrakannya. Item persamaan di kolom 2 kurang abstrak, adapun item di kolom 3 lebih abstrak.

Kompleksitas tugas juga telah diteliti secara sistematis dalam berbagai konteksnya. Peneliti dalam bidang "information processing" , "decision making" dan "goal setting" menekankan pentingnya jumlah, keberagaman, variabilitas, ambiguitas, dan keterkaitan informasi yang harus diproses untuk mengevaluasi alternatif-alternatif yang dimungkinkan dan membuat suatu keputusan. Wood (1986) sebagai contoh, mendiskusikan tiga dimensi kompleksitas tugas, yaitu (1) component complexity / kompleksitas dalam komponen (contoh, jumlah / banyaknya clues yang harus diperhatikan dan diintegrasikan, banyaknya tuntutan), (2) coordinative complexity / kompleksitas dalam koordinasi (contoh, timing I saat yang tepat tugas diselesaikan atau tugastugas yang merupakan rangkaian, panjangnya rangkaian tugas), dan perubahan dalam rangkaian sebab-akibat atau hubungan awal-akhir. Semakin kompleks item semakin membutuhkan manipulasi mental dari orang-orang untuk belajar sesuatu atau memecahkan masalah melihat/mencari kaitan (seeing connections), menggambarkan perbedaan (drawing distinctions), mengisi kekosongan (filling in gaps), memanggil kembali dan menerapkan informasi yang relevan (recalling and applying relevant information), melihat hubungan sebab-akibat dengan tajam (discerning cause and effect relations), menginterpretasikan lebih banyak informasi (interpreting more bits of information), dan sebagainya.

Merujuk pada paparan di atas maka satu definisi kerja (working definitions) dari $g$ yang berguna untuk memahami kompetensi seharihari adalah kemampuan untuk menghadapi kompleksitas (ability to deal with complexity). Definisi ini dapat diterjemahkan ke dalam dua kemampuan yaitu kemampuan untuk belajar material yang memiliki kompleksitas menengah dengan cepat dan efisien (the ability to learn moderately complex material quickly and efficiently), dan kemampuan untuk menghindari kekeliruan kognitif (the ability to avoid cognitive errors). Oleh karena itu, secara 
umum $g$ adalah kemampuan untuk memproses informasi. $g$ bukan saja menunjukkan seberapa banyak / jumlah pengetahuan yang harus diakumulasikan. Orang dengan level $g$ tinggi cenderung memiliki jumlah pengetahuan yang lebih besar, tetapi akumulasi ini adalah hasil / produk dari kemampuannya untuk memahami dengan lebih baik dan belajar dengan lebih cepat. Mereka juga lebih baik dalam menjalankan tugas sehari-hari untuk alasan yang sama. Peneliti tentang kemampuan membaca setidak-tidaknya mengkonfirmasikan bahwa $g$ memiliki nilai praktis yang tinggi dalam kehidupan sehari-hari. Mereka menyimpulkan dengan mengejutkan bahwa perbedaan dalam membaca yang sifatnya fungsional (menggunakan peta, membaca menu, menggunakan form pemesanan (order form), dan menggunakan slip deposit bank ; memahami artikelartikel baru dan pilihan-pilihan asuransi dan semacam-nya) dan membaca untuk kepentingan kesehatan / health literacy ( memahami instruksi dokter, dan memahami label obatobatan, mengambil pengobatan secara tepat, dan sebagainya) merefleksikan perbedaan dalam kemampuan umum untuk memproses informasi (Gottfredson, 1997, 2002).

Jadi, $g$ adalah alat/tool yang bersifat generik, memiliki sifat adaptif untuk memproses informasi apakah dalam tes kemampuan mental, pekerjaan, kehidupan sehari-hari, dalam pelatihan dan sesudahnya.

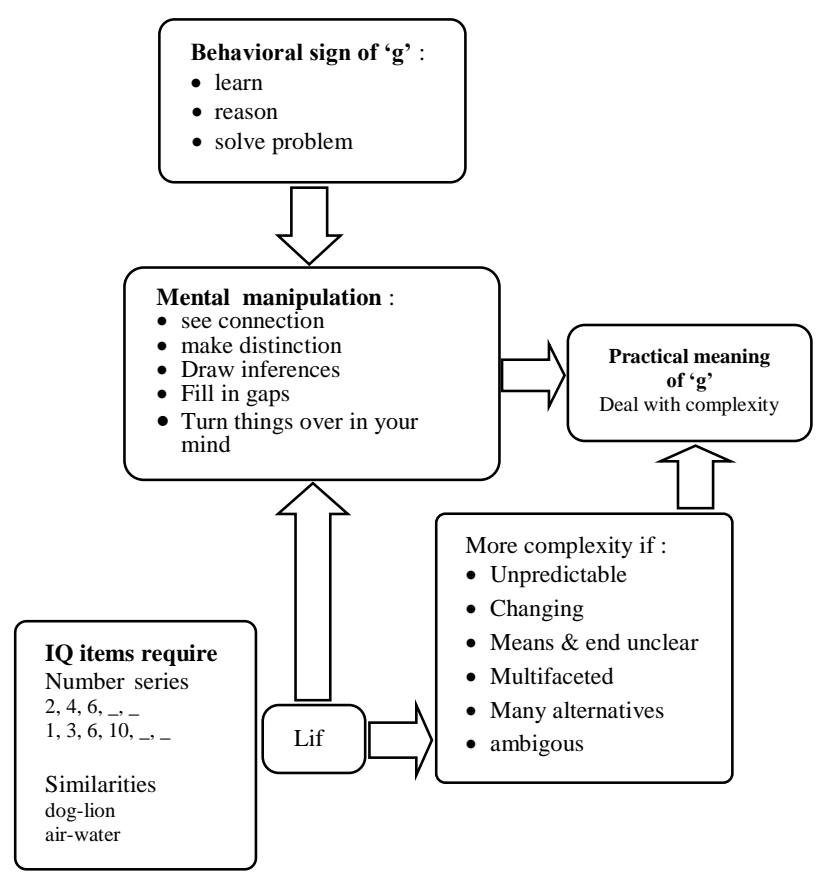

Gambar 2. Kaitan g-factor, IQ, dan kehidupan

Tes kecerdasan ada yang dikonstruksi untuk mengukur g-factor saja (tes seperti ini biasanya hanya terdiri dari satu subtes saja), ada juga yang dikonstruksi untuk mengukur kemampuan mental spesifik atau s-factor (tes kecerdasan seperti ini biasanya terdiri dari beberapa subtes). Menurut Gottfredson meskipun setiap tes yang mengukur kemampuan mental dimaksudkan untuk mengukur kemampuan mental spesifik, tes tersebut juga pasti merefleksikan $g$ dalam derajat yang berbedabeda. Sebaliknya karena setiap tes kemampuan mental "terkontaminasi" oleh efek dari kemampuan mental spesifik, maka tidak ada satu tes kemampuan mental yang hanya mengukur "g-factor". Bahkan skor-skor dari tes IQ yang biasanya menggabungkan 12 subtes yang mengukur kecakapan kognitif spesifik - mengandung "ketidakmurnian" (impurities) yang mencerminkan kecakapan kognitif spesifik tersebut. Secara praktis ketidakmurnian ini 
sering tidak menunjukkan perbedaan sehingga $g$ dan IQ sering dipertukarkan. Tetapi secara statistik peneliti dapat memisahkan komponen $g$ dari IQ. Kemampuan untuk mengisolasi $g$ telah menjadi penelitian yang revolusioner dalam isu kecerdasan umum, karena hal itu mengizinkan peneliti untuk memperlihatkan bahwa nilai preditif tes kemampuan mental berasal dari faktor global ini daripada berasal dari bakat spesifik yang diukur oleh tes kecerdasan.

\section{Intelligenz Struktur Test ( IST)}

IST-70 (Intelligenz Struktur Test) merupakan tes kognitif pertama yang diadministrasikan secara kolektif. Tes ini dikembangkan di Jerman oleh Rudolf Amthauer. Hal yang mendasari dikembangkannya tes ini adalah adanya keinginan untuk menggali dan mengukur inteligensi secara tersendiri, terlepas dari aspek kepribadian. Amthauer menganggap bahwa inteligensi adalah suatu struktur tersendiri di dalam keseluruhan struktur kepribadian seorang manusia. Inteligensi merupakan suatu keseluruhan struktur yang terdiri dari kemampuan-kemampuan jiwa dan rohani, yang berfungsi sedemikian rupa sehingga memberikan kemampuan bagi manusia untuk bertindak sebagai pelaksana dalam dunianya. Hipotesa yang dikembangkan oleh Amthauer adalah bahwa kemampuan-kemampuan intelektual memiliki suatu struktur tertentu yang mengikuti suatu hierarki tertentu pula. Berdasarkan pengalaman empirik, penelitian, dan eksperimen, Amthauer melakukan pengujian antara konsep teoritik dan praktek di lapangan, dan akhirnya sampai kepada kesimpulan bahwa faktor-faktor intelektual yang diukur oleh IST merupakan faktor yang bersifat spesifik ( $s$ factor). Hasil penelitiannya membuktikan adanya interkorelasi yang rendah antar subtes $(r=$ $0,25)$, sedangkan korelasi antara subtes dengan jumlah keseluruhan subtes rendah pula $(r=$ $0,60)$.

Keseluruhan IST terdiri dari sembilan subtes yang mengukur faktor spesifik $(s-$ factor), yaitu

1. SE (Satzergaenzung), pembentukan pendapat, common sense, penekanan pada "berpikir konkrit praktis", sense of reality, mandiri dalam berpikir. Yang diukur adalah judgement subyek, artinya apakah ia mampu menilai apakah ia mandiri, atau apakah ia salah kaprah.

2. WA (Wortauswahl), menangkap inti makna atau pengertian yang disampaikan dalam bahasa, rasa bahasa, berpikir dengan bahasa secara induktif, kepekaan menyelami perasaan, empati, komponen-komponen reseptif/serapan. Yang diukur adalah kecepatan subyek dalam menangkap dan menyerap maksud/inti/ makna/ isi pokok dari perintah atau instruksi dan informasi yang disampaikan secara verbal oleh orang lain.

3. AN (Analogien), kemampuan menghubungkan atau menyusun kombinasi, fleksibilitas / kelincahan dan kemampuan berganti dalam berpikir; kemampuan menangkap dan mengalihkan / memindahkan hubungan atau keterikatan; kejelasan dan keteraturan logis dalam berpikir, bertentangan dengan cara pemecahan masalah yang 
bersifat kira-kira. Yang diukur adalah proses berpikir yang mencakup analisis, judgement dan kesimpulan

4. GE (Gemeinsamkeiten), kemampuan mengabstraksikan pembentukan pengertian atau pemahaman, berpikir logis dengan bahasa. Yang diukur adalah kemampuan bernalar secara logis.

5. ME (Merkaufgaben), kemampuan mengingat atau menyimpan kata-kata yang telah dipelajari, menyimpan lama dalam ingatan, daya ingat atau ingatan. Yang diukur adalah apakah ingatan subyek dapat dipercaya atau tidak?, berkaitan dengan perhatian, konsentrasi dan kemampuan mencamkan, ingatan yang tajam atau tumpul.

6. RA (Rechnaufgaben), berpikir secara praktis dengan berhitung; berpikir matematis, logis dan lugas; bernalar, berpikir runtut dalam membuat kesimpulan. Yang diukur adalah kemampuan memecahkan masalah praktis dengan berhitung.

7. $Z R$ (Zahlenreihen), berpikir teoretis berhitung; berpikir induktif dengan angkaangka; kelincahan, fleksibilitas dan kemampuan berpikir dengan mengubah atau menggantikan cara atau pendekatan; komponen-komponen ritmis atau berirama. Yang diukur adalah kemampuan berhitung yang didasarkan pada pendekatan analitis atas informasi faktual dalam bentuk angka, sehingga ditemukan hubungan antara angka-angka tersebut. Dapat juga berarti berpikir lincah, fleksibel dan mudah beralih dari satu cara ke cara yang lain.
8. FA (Figurenauswahl), kemampuan membayangkan, kaya dalam membayangkan, berpikir visual menyeluruh, komponenkomponen konstruktif membangun. Yang diukur adalah kemampuan imajinasi dan kreativitas subyek yang dibantu kemampuan membayangkan secara menyeluruh.

9. WU (Wuerferlaufgaben), kemampuan membayangkan ruang, komponen-komponen teknis konstruktif. Yang diukur adalah kemampuan analitis yang disertai kemampuan membayangkan secara antisipatif pada perubahan keadaan ruang, ada fungsi kreativitas dan kemampuan menyusun / mengkonstruksikan perubahan, imajinasi dan fleksibilitas.

\section{Wonderlic Personnel Test (WPT)}

WPT merupakan tes yang dikembangkan oleh E.F. Wonderlic pertama kali pada tahun 1936. Tes ini didisain untuk membandingkan kemampuan kognitif umum individu dengan nilai normatif bagi beragam karir atau jenis pekerjaan. Dengan tes ini kita dapat meningkatkan pemahaman akan kemampuan belajar, memahami instruksi dan memecahkan masalah yang dimiliki individu. Tes ini juga dapat digunakan untuk menentukan kemampuan individu dalam menjalankan fungsinya dengan baik dalam posisi pekerjaan tertentu. Tes ini terdiri dari 50 soal yang terdiri dari soal-soal verbal, hitungan dan gambar / nonverbal yang harus dikerjakan dalam 12 menit. Tes ini mengukur kemampuan kognitif umum atau kemampuan inteligensi umum atau ' $g$ '-factor. Kemampuan kognitif merupakan 
term yang digunakan untuk mendeskripsikan pada tingkat mana kemam-puan individu dalam belajar, memahami instruksi dan memecahkan persoalan berada/ berfungsi. WPT mengukur kemampuan mental umum, tapi tidak mengukur seberapa baik individu akan menggunakan kemampuan yang dimilikinya. Oleh karena itu WPT hanya mengukur potensi kecerdasan individu. Semakin tinggi nilai / skor individu maka tidak saja ia akan memperoleh pengetahuan yang lebih banyak dari pelatihan secara formal, tapi ia pun akan semakin efektif dalam belajar dari pengalaman. Semakin rendah skor yang diperoleh individu, maka individu akan semakin membutuhkan instruksi yang rinci, langsung pada prakteknya, semakin membutuhkan waktu yang lama dan pengulangan-pengulangan serta pengawasan / supervisi yang terus-menerus.

Skor yang diperoleh individu kemudian dibandingkan dengan skor minimum yang disyaratkan untuk posisi jabatan atau tingkat pendidikan tertentu. Skor rata-rata untuk semua jenis pekerjaan adalah sekitar 21. Skor ini juga skor rata-rata individu lulusan sekolah menengah atas. Adapun skor individu lulusan perguruan tinggi rata-rata adalah 29. Semakin tinggi skor ditampilkan oleh individu maka individu semakin cepat dalam belajar, akan semakin menguasai materi-materi yang lebih kompleks dan akan membuat penilaian yang lebih baik ketika informasi yang didapat kurang. Semakin rendah skor individu maka individu membutuhkan lebih banyak waktu untuk belajar sesuatu, membutuhkan instruksi yang spesifik dan prosedur kerja yang terstandar dan menunjukkan rutinitas yang tinggi.

\section{Metode}

Rancangan penelitian ini adalah penelitian korelasional. Yang akan dikorelasikan adalah :

1. Antar subtes IST, yang terdiri dari SE, WA, AN, GE, ME, RA, ZR, FA, WU ;

2. Hasil tes WPT dan IST, yaitu skor total WPT dan skor total IST dan WPT dengan subtes-subtes IST

Untuk menentukan keeratan hubungan/ korelasi di atas digunakan analisis korelasi product moment (pearson), karena data berskala interval. Adapun rumusnya sebagai berikut:

$$
r_{X_{i}, X_{j}}=\frac{n \sum_{l=1}^{n} x_{i l} x_{j l}-\sum_{l=1}^{n} x_{i l} \sum_{l=1}^{n} x_{j l}}{\sqrt{\left\{n \sum_{l=1}^{n} x_{i l}^{2}-\left(\sum_{l=1}^{n} x_{i l}\right)^{2}\right\}\left\{n \sum_{l=1}^{n} x_{j l}^{2}-\left(\sum_{l=1}^{n} x_{j l}\right)^{2}\right\}}}
$$

Hipotesis yang diajukan untuk mengetahui ada atau tidaknya hubungan linear antar subtest yang bersangkutan secara umum dinyatakan sebagai berikut :

$\mathrm{H}_{0}: \rho=0$ (Tidak terdapat hubungan antar subtest IST SW)

$\mathrm{H}_{1}: \rho \neq 0$ (Terdapat hubungan antar subtest IST SW)

Pengujian hipotesis tersebut menggunakan statistik uji $t$ dengan rumus seperti dibawah ini :

$t_{\text {hitung }}=\frac{r_{X_{i}, X_{j}} \sqrt{n-2}}{\sqrt{1-r_{X_{i}, X_{j}}^{2}}} \sim t_{(\alpha / 2, n-2)}$ 
Kriteria uji : Tolak $\mathrm{H}_{0}$ jika $\left|t_{\text {hitung }}\right|>t_{\text {tabel }}$, artinya terdapat hubungan yang signifikan antara subtest $X_{i}$ dengan subtest $X_{j}$ pada taraf signifikansi $\alpha=0.05$. Atau suatu hubungan dinyatakan signifikan apabila mempunyai nilai signifikansi yang lebih kecil dari 0.05 (Sig. < 0.05). Untuk perhitungan analisis korelasi di gunakan program SPSS versi 17.00.

3. Selain korelasi di atas, ingin diketahui pula apakah hasil tes WPT dan tes IST berbeda. Untuk maksud ini digunakan uji perbedaan dengan uji statistik MannWhitney $\mathrm{U}$ karena data ternyata tidak berdistribusi normal.

Subyek dalam penelitian ini adalah calon mahasiswa Fakultas Kedokteran dan calon mahasiswa Fakultas Psikologi Universitas Islam Bandung yang mengikuti seleksi Penerimaan Mahasiswa Baru tahun 2009. Pengambilan sampel dilakukan secara purpossive sampling, yaitu calon mahasiswa yang mengikuti PMB gelombang 1 dan PMB gelombang 3. Seluruhnya berjumlah 558 subyek yang terdiri dari 307 calon mahasiswa Fakultas Kedokteran dan 251 calon mahasiswa Fakultas Psikologi. Calon mahasiswa ini berusia antara $16-20$ tahun.

\section{Hasil}

Berikut adalah hasil penelitian:

\section{Hubungan antar Subtes IST}

Tabel 2 menunjukkan bahwa nilai korelasi antar subtest IST yang paling rendah adalah antara subtest ME dengan WU yaitu sebesar 0.223 , sedangkan hubungan tertinggi dimiliki oleh subtest RA dengan ZR sebesar 0.680. Pada kolom terakhir dalam Tabel 2 ditunjukkan pula besarnya hubungan antara masing-masing subtest IST dengan total IST. Subtest RA memiliki hubungan paling erat dengan total dibandingkan subtest lainnya yaitu sebesar 0.781, sementara nilai korelasi terendahnya dimiliki oleh subtest ME dengan nilai korelasi sebesar 0.580 .

Tabel 2. Hubungan Antar Subtest IST

\begin{tabular}{|c|c|c|c|c|c|c|c|c|c|c|}
\hline IST & SE & WA & AN & GE & ME & RA & ZR & FA & WU & TOTAL \\
\hline \hline $\begin{array}{l}\text { SE } \\
\text { SW }\end{array}$ & & & & & & & & & & 0.694 \\
\hline $\begin{array}{l}\text { WA } \\
\text { SW }\end{array}$ & 0.513 & & & & & & & & & 0.656 \\
\hline $\begin{array}{l}\text { AN } \\
\text { SW }\end{array}$ & 0.561 & 0.487 & & & & & & & & 0.698 \\
\hline $\begin{array}{l}\text { GE } \\
\text { SW }\end{array}$ & 0.481 & 0.472 & 0.461 & & & & & & & 0.696 \\
\hline $\begin{array}{l}\text { ME } \\
\text { SE }\end{array}$ & 0.280 & 0.306 & 0.322 & 0.342 & & & & & & 0.580 \\
\hline $\begin{array}{l}\text { RA } \\
\text { SW }\end{array}$ & 0.500 & 0.447 & 0.528 & 0.464 & 0.354 & & & & & 0.781 \\
\hline $\begin{array}{l}\text { ZR } \\
\text { SW }\end{array}$ & 0.444 & 0.455 & 0.504 & 0.444 & 0.409 & 0.680 & & & & 0.773 \\
\hline $\begin{array}{l}\text { FA } \\
\text { SW }\end{array}$ & 0.339 & 0.335 & 0.399 & 0.334 & 0.233 & 0.478 & 0.401 & & & 0.607 \\
\hline $\begin{array}{l}\text { WU } \\
\text { SW }\end{array}$ & 0.352 & 0.315 & 0.340 & 0.310 & 0.223 & 0.466 & 0.427 & 0.457 & & 0.636 \\
\hline
\end{tabular}

Sumber : Hasil Analisis Data PMB, 2009

Untuk menentukan sejauhmana tingkat keeratan hubungan antar sub-test dapat menggunakan aturan Guilford (2000) yaitu nilai korelasi kurang dari 0.2 dikategorikan sangat lemah (very low correlation), antara 0.21-0.40 dikategorikan hubungannya lemah (low correlation), 0.41-0.70 dikategorikan hubungannya cukup kuat (moderate correlation), 0.710.90 dikategorikan hubungannya kuat (high correlation), sedangkan jika lebih dari 0.91 dikategorikan memiliki hubungan yang sangat kuat (very high correlation). Untuk kasus data subtest IST ini terdapat dua subtest yang memiliki hubungan yang kuat dengan jumlah IST yaitu subtest RA dan ZR. Sedangkan antar subtest hubungannya cukup kuat dan sebagian lagi termasuk kategori korelasi lemah. 
Uji signifikansi hubungan antar subtest IST, semua nilai signifikansinya mendekati nol (Sig. 0.000) dan nilai t hitungnya lebih besar dari 2. Sehingga hipotesis nol yang menyatakan tidak terdapat hubungan antar subtest IST ditolak. Dengan demikian dapat disimpulkan bahwa terdapat hubungan positif yang signifikan antar subtest IST maupun dengan totalnya.

\section{Hubungan antara WPT dengan Subtest IST}

Untuk melihat hubungan antara variabel WPT dengan subtest IST, caranya sama seperti analisis korelasi antar subtest IST. Hasil perhitungannya disajikan dalam tabel berikut ini:

Tabel 3. Hubungan antara WPT dengan Subtest IST

\begin{tabular}{|l|c|c|c|c|c|c|c|c|c|c|}
\hline IST & SE & WA & AN & GE & ME & RA & ZR & FA & WU & TOTAL \\
\hline \hline & & & & & & & & & & \\
\hline WPT & 0.375 & 0.435 & 0.483 & 0.402 & 0.428 & 0.566 & 0.631 & 0.360 & 0.306 & 0.641 \\
\hline
\end{tabular}

Sumber : Hasil Analisis Data PMB, 2009

Pada Tabel 3 terlihat bahwa semua nilai korelasinya bertanda positif, artinya terdapat hubungan yang searah antara WPT dengan subtest IST. Sebagian nilai korelasinya di atas 0.4 (kecuali hubungan antara WPT dengan subtest SE , FA dan WU ) yang menunjukkan hubungan linear antara WPT dengan subtest IST sekurang-kurangnya dikategorikan memiliki hubungan yang cukup erat. Hubungan WPT dengan IST dikategorikan sebagai korelasi yang cukup kuat yaitu sebesar 0.641. Sementara subtest yang memiliki nilai korelasi tertinggi dengan WPT adalah subtest ZR sebesar 0.631. Subtest IST yang memiliki hubungan terkecil dengan WPT adalah WU, nilai korelasinya sebesar 0.306 .
Uji signifikansi hubungan antara WPT dengan subtest IST. Semua nilai signifikansinya mendekati nol (Sig. 0.000) dan nilai $t$ hitungnya lebih besar dari 2. Sehingga hipotesis nol yang menyatakan tidak terdapat hubungan antara WPT dengan subtest IST ditolak. Dengan demikian dapat disimpulkan bahwa terdapat hubungan positif yang signifikan antara WPT dengan subtest IST maupun dengan total IST itu sendiri.

\section{Uji Perbedaan WPT dan IST}

Untuk melakukan uji perbedaan hasil WPT dan IST, peneliti menggunakan data IQ yang diperoleh dari kedua tes kecerdasan tersebut. Sebelum melakukan uji perbedaan kedua data IQ tersebut, data tersebut dilakukan uji normalitas terlebih dahulu. Hasilnya dapat dilihat pada tabel berikut:

Tabel 4. Uji Normalitas IQ

Tests of Normality

\begin{tabular}{|c|c|c|c|c|c|c|}
\hline & \multicolumn{3}{|c|}{ Kolmogorov-Smirnov } & \multicolumn{3}{|c|}{ Shapiro-Wilk } \\
\hline & Statistic & $\mathrm{df}$ & Sig. & Statistic & df & Sig. \\
\hline IQ IST SW & .074 & 1653 & .000 & .979 & 1653 & .000 \\
\hline
\end{tabular}

Sumber : Hasil Analisis Data PMB

Berdasarkan Tabel 4 diperoleh nilai statistik uji Kolmogorov-Smirnov sebesar 0.074 dengan nilai signifikansinya mendekati nol (Sig. 000), maka dapat disimpulkan data tidak Normal. Untuk menguji perbedaan nilai tengah IQ pada saat kondisi normalitas data tidak terpenuhi dapat menggunakan pendekatan metode nonparametrik menggunakan statistik uji Mann-Whitney U untuk sampel besar akan mengikuti distribusi $\mathrm{Z}$. 
Dari perhitungan diperoleh nilai statistik uji Mann-Whitney U sebesar 142181.0 dan nilai $\mathrm{Z}=-2.413$. Nilai signifikansi uji ini sebesar 0.016 (Asymp. Sig. (two-tiled) 0.016) yang lebih kecil dari 0.05 , sehingga dapat disimpulkan bahwa terdapat perbedaan yang signifikan antara IQ WPT dengan IQ IST pada taraf kepercayaan 95\%. Hasil perhitungan uji Mann-Whitney untuk perbedaan nilai tengah IQ WPT dan IQ IST disajikan dalam tabel berikut ini.

Tabel 5.Uji Perbedaan Nilai Tengah IQ WPT dan IQ IST

\begin{tabular}{|l|r|}
\multicolumn{2}{|c|}{ Test Statistics $^{\text {a }}$} \\
\begin{tabular}{|l|r|}
\hline \multicolumn{1}{|c|}{ IQ } \\
\hline Mann-Whitney U & 142181.0 \\
Wilcoxon W & 297584.0 \\
Z & -2.413 \\
Asymp. Sig. (2-tailed) & .016 \\
\hline
\end{tabular}
\end{tabular}

a. Grouping Variable: KEL

Sumber : Hasil Analisis Data PMB, 2009

\section{Pembahasan}

\section{Hubungan antar subtes IST}

Dari tabel 2 Hubungan Antar Subtes IST dapat dilihat sebagai berikut. Dimulai dengan subtes pertama yaitu SE yang mengukur kemampuan judgement subyek apakah ia mampu menilai apakah ia mandiri, atau apakah ia salah kaprah. Akan dilihat hubungan SE dengan subtes yang lain.

1. Korelasi SE dengan WA adalah 0,513. Artinya keeratan hubungan antara SE dan WA tersebut dapat dikatakan cukup kuat. WA mengukur kecepatan subyek dalam menangkap dan menyerap maksud/inti/ makna/ isi pokok dari perintah atau instruksi dan informasi yang disampaikan secara verbal oleh orang lain. Nilai korelasi yang cukup kuat mengindikasikan bahwa SE dan WA mengukur kemampuan mental yang sama.

2. Korelasi SE dengan AN adalah 0,561. Artinya keeratan hubungan antara kedua subtes tersebut cukup kuat. AN adalah subtes yang mengukur proses berpikir yang mencakup analisis, judgement dan penarikan kesimpulan. Nilai korelasi kedua subtes tersebut cukup kuat mengindikasikan bahwa SE dan AN mengukur kemampuan mental yang sama

3. Korelasi SE dengan GE adalah 0,481 Artinya keeratan hubungan antara kedua subtes tersebut lemah. Adapun GE adalah subtes yang mengukur kemampuan bernalar secara logis. Nilai korelasi yang rendah mengindikasikan bahwa kedua subtes tersebut mengukur kemampuan mental yang berbeda.

4. Korelasi SE dan ME adalah 0,280. Artinya keeratan hubungan antara kedua subtes tersebut lemah. ME adalah subtes yang mengukur daya ingat. Nilai korelasi yang rendah mengindikasikan bahwa kedua subtes tersebut mengukur kemampuan mental yang berbeda.

5. Korelasi SE dan RA adalah 0,500. Artinya keeratan hubungan antara kedua subtes tersebut cukup cenderung lemah. RA adalah subtes yang mengukur kemampuan memecahkan masalah praktis dalam berhitung. Nilai korelasi yang cukup cenderung lemah mengindikasikan bahwa SE 
dan RA mengukur kemampuan mental yang berbeda.

6. Korelasi SE dan ZR adalah 0,444. Artinya keeratan hubungan antara kedua subtes tersebut lemah. ZR adalah subtes yang mengukur kemampuan berhitung yang didasarkan pada pendekatan analitis atas informasi faktual dalam bentuk angka, sehingga ditemukan hubungan antara angka-angka tersebut. Nilai korelasi yang rendah antara kedua subtes tersebut mengindikasikan bahwa SE dan ZR mengukur kemampuan mental yang berbeda.

7. Korelasi SE dan FA adalah 0,339. Artinya keeratan hubungan antara kedua subtes tersebut lemah. FA adalah subtes yang mengukur kemampuan berpikir secara menyeluruh / komprehensif. Nilai korelasi yang rendah antara kedua subtes tersebut mengindikasikan SE dan FA mengukur kemampuan mental yang berbeda.

8. Korelasi SE dan WU adalah 0,352. Artinya keeratan hubungan antara kedua subtes tersebut lemah. WU adalah subtes yang mengukur kemampuan daya bayang ruang. Nilai korelasi yang rendah mengindikasikan bahwa SE dan WU mengukur kemampuan mental yang berbeda.

Selanjutnya dari Tabel 2 dapat dilihat hubungan antar Subtes IST yaitu WA dengan subtes yang lain. Dan seterusnya.

\section{Hubungan antara WPT dan IST}

Agar lebih memberikan hasil yang meyakinkan peneliti mencoba mengkorelasikan WPT sebagai tes kecerdasan yang mengukur g-factor dengan IST. Dari Tabel 3 dapat dilihat Hubungan Antara WPT dengan IST.

1. Korelasi WPT dengan subtes SE IST adalah 0,375. Artinya keeratan hubungan antara WPT dan subtes SE IST tergolong lemah. Hal tersebut mengindikasikan bahwa WPT dan SE IST mengukur kemampuan yang berbeda. Ini memperkuat bukti di atas bahwa SE mengukur s-factor.

2. Korelasi WPT dengan subtes WA IST adalah 0,435 . Ini artinya keeratan hubungan antara WPT dengan subtes WA IST cenderung lemah. Hal tersebut mengindikasikan bahwa WPT dan WA IST mengukur kemampuan yang berbeda. Ini memperkuat bukti diatas bahwa WA IST mengukur $s$-factor.

3. Korelasi WPT dengan AN IST adalah 0,483 . Ini artinya keeratan hubungan antara WPT dan AN IST cenderung lemah. Ini mengindikasikan bahwa WPT dan AN IST mengukur kemampuan yang berbeda. Ini memperkuat bukti bahwa AN IST mengukur s-factor.

4. Korelasi WPT dengan GE IST adalah 0,402 . Ini artinya keeratan hubungan antara WPT dan GE IST tergolong lemah. Ini mengindikasikan bahwa WPT dan GE IST mengukur kemampuan yang berbeda. Ini memperkuat bukti bahwa GE IST mengukur s-factor.

5. Korelasi WPT dengan ME IST adalah 0,428 . Ini artinya keeratan hubungan antara WPT dan ME IST tergolong lemah. Ini mengindikasikan bahwa WPT dan ME IST mengukur kemampuan yang berbeda. 
Ini memperkuat bukti bahwa ME IST mengukur s-factor.

6. Korelasi WPT dengan RA IST adalah 0,566. Ini artinya keeratan hubungan antara WPT dan RA IST cukup kuat. Ini mengindikasikan bahwa RA mengukur kemampuan yang sama dengan WPT, dalam hal ini adalah kemampuan memecahkan masalah.

7. Korelasi WPT dengan ZR IST adalah 0,631 . Ini artinya keeratan hubungan antara WPT dan ZR IST cukup kuat. Ini mengindikasikan bahwa WPT dan ZR IST mengukur kemampuan yang sama yaitu kemampuan menalar.

8. Korelasi antara WPT dengan FA IST adalah 0,360 . Ini artinya keeratan hubungan antara keduanya lemah. Ini mengindikasikan keduanya mengukur kemampuan yang berbeda. Ini memperkuat bukti bahwa FA IST mengukur $s$-factor.

9. Korelasi WPT dengan WU IST adalah 0,306 . Ini artinya keeratan hubungan antara keduanya lemah. Ini mengindikasikan keduanya mengukur kemampuan yang berbeda. Ini memperkuat bukti bahwa WU IST mengukur s-factor.

10. Korelasi WPT dengan total IST adalah 0,641 . Ini artinya keeratan hubungan antara kedua hal tersebut cukup kuat. Ini mengindikasikan bahwa WPT dan total IST mengukur g-factor.

\section{Perbedaan WPT dan IST}

Dari Uji Perbedaan IQ hasil tes WPT dan IQ hasil tes IST diperoleh bahwa terdapat perbedaan yang signifikan antara IQ hasil tes WPT dengan IQ hasil tes IST. Hal ini dapat dijelaskan sebagai berikut. WPT adalah tes kecerdasan yang mengukur $g$-factor atau faktor umum yang mengukur kemampuan belajar, bernalar dan memecahkan masalah. Tes ini tidak terbagi ke dalam subtes-subtes yang mengukur kemampuan spesifik. Tes ini hanya mengukur faktor umum tersebut di atas sebagai satu kesatuan, sehingga hasilnya murni menggambarkan kemampuan g-factor.g-factor ini direpresentasikan dalam nilai IQ yang diperoleh dari pengukuran menggunakan WPT.

Adapun IST adalah tes kecerdasan yang dikonstruksi untuk mengukur kemampuan spesifik-kemampuan spesifik. IST terdiri dari 9 subtes yang setiap subtesnya mengukur kemampuan yang berbeda dan spesifik. Meskipun setiap subtes yang ada dimaksudkan untuk mengukur kemampuan mental spesifik, subtessubtes tersebut juga merefleksikan $g$ dalam derajat yang berbeda-beda. Sebaliknya karena setiap subtes "terkontaminasi" oleh efek dari kemampuan mental spesifik, maka tidak ada satu subtes yang hanya mengukur " $g$-factor". Ketika diperoleh skor IST dari total IST maka skor tersebut tidak murni mengukur g-factor. Dikatakan mengandung 'ketidakmurnian' karena ada faktor pengotor sebagai efek dari kemampuan mental spesifik. Oleh karena itu ketika skor yang 'tidak murni' mengukur $g$ factor ini dikonversikan ke nilai IQ maka nilai IQ yang diperolehpun tidak murni menunjukkan skor IQ yang sesungguhnya. Skor IQ yang diperoleh akan menjadi lebih tinggi 


\section{Simpulan dan Saran}

Kesimpulan

Sesuai dengan tujuan penelitian yang ditetapkan maka dari penelitian ini dapat disimpulkan :

1. Dari korelasi antar subtes IST yang diperoleh dapat disimpulkan bahwa IST adalah tes kecerdasan yang mengukur $s$-factor

2. Dari korelasi total IST dengan WPT diperoleh bahwa IST juga tes kecerdasan yang mengukur $g$-factor .

3. Dari korelasi subtes IST dengan WPT diperoleh bahwa IST adalah tes kecerdasan yang mengukur $s$-factor.

4. Dari uji perbedaan IQ hasil WPT dan IST diperoleh bahwa ada perbedaan IQ hasil WPT dan IST. Perbedaan ini terjadi karena konstruksi tes WPT dan IST berbeda. WPT dikonstruksi untuk mengukur $g$ factor. Adapun IST dikontruksi untuk mengukur kemampuan spesifik / s-factor dan g-factor. $g$-factor yang diukur oleh IST tidak murni mengukur $g$-factor karena adanya faktor pengotor dari efek kemampuan spesifik.

Saran

Berdasarkan hasil penelitian di atas, maka peneliti menyarankan :

1. Dalam praktek, tes kecerdasan IST sebaiknya tidak dipergunakan sebagai alat tes yang berdiri sendiri untuk mengukur kemampuan umum / g-factor.

2. Untuk mendapatkan kemampuan umum / g-factor yang lebih murni hendaknya tes kecerdasan IST digunakan bersama-sama dengan alat tes kecerdasan lain yang hanya mengukur g-factor.

3. Tes kecerdasan IST dipergunakan sebagai alat tes kecerdasan yang mengukur kemampuan spesifik / s-factor

\section{Daftar Pustaka}

Anastasi, A , \& Urbina, S. (1997) Psychological Testing ( seventh edition). Upper Sadle River, $\mathrm{Nj}$. Prentice-Hall, Inc.

Gottfredson, Linda S. (1997) Mainstream Science on Intelligence : An Editorial With 52 Signatories, History, and Bibliography dalam journal INTELLIGENCE 24 (1) 13-23. Ablex Publishing Corporation.

Gottfredson, Linda S. (1998). The General Intelligence Factor dalam Human Intelligence. Scientific American Inc. P $24-$ 28

Gottfredson, Linda S (2002). Where and Why g Matters : Not a Mys-tery dalam Journal Human Perfor-mance , 15 (1/2), 25 - 46. Law-rence Erlbaum Associates, Inc.

Gottfredson, Linda S. (2004). Life, Death \& Intelligence dalam Jour-nal of Cognitive Education and Psychology (online), 4, 1, 23-46. www.iacep.coged.org.

Sattler, J.M. (2001). Assessment of Children Cognitive Applications (fourth edition). San Diego, Jerome M. Sattler, Publisher, Inc.

Sattler, J.M (2008). Assessment of Children Cognitive Foundations (Fifth Edition). San Diego. Jerome M. Sattler, Publisher, Inc.

Siti Qodariah. (2006). Wonderlic Personnel Tes. Makalah disampaikan pada Seminar Intern Fakultas Psikologi Universitas Islam Bandung, Bandung Juni 2006

Sumiharso (2007). Menggagas Ulang Kecerdasan: Kepentingan Relatif Faktor Kecerdasan Umum (the g-factor) dalam Kehidupan Sehari-hari. Makalah disampaikan pada Seminar Intern Fakultas Psikologi Universitas Islam Bandung, Bandung 24 November 2007. 
Sumiharso (2008). Intelligence: History Behind The Theories. Makalah disampaikan pada Seminar "Pembahasan Teori CHC dan Aplikasinya dalam Pengukuran Inteligensi" Laboratorium Psikologi Fakultas Psikologi Univesitas Islam Bandung, Bandung 19 Juli 2008.

Sumintardja, E.N, \& Rismiyati, E.K (1999). Aspek Inteligensi dan Pengukurannya dalam Konsep Dasar Penguasaan Diagnostik. Makalah disampaikan pada pelatihan Psikodiagnostik Fakultas Psikologi Universitas Islam Bandung. Bandung 11, 12 dan 13 November 1999 